MSABR 02-07

Morrison School of Agribusiness and Resource Management

Faculty Working Paper Series

\title{
Brazil's Domination of the World Sugar Market
}

Troy G. Schmitz, James L. Seale, Jr., and Peter J. Buzzanell

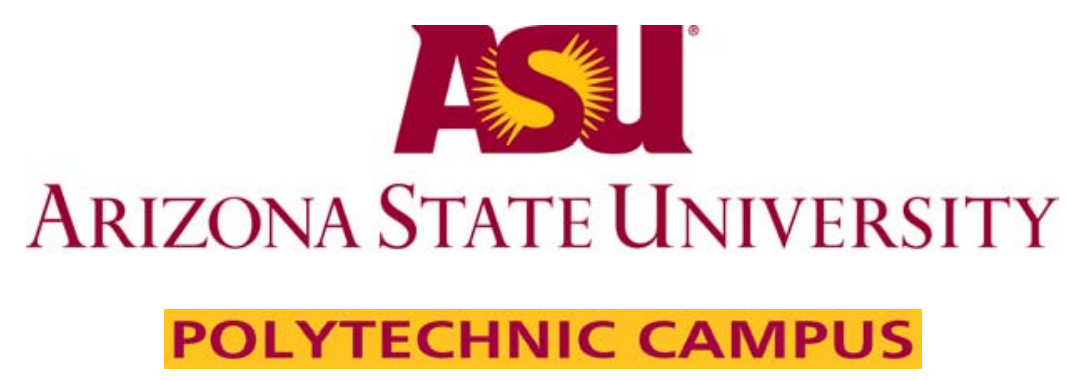




\section{Brazil's Domination of the World Sugar Market \\ Troy G. Schmitz, James L. Seale, Jr., and Peter J. Buzzanell}

Brazil currently dominates the world sugar market in almost all aspects. It is the world's largest producer of sugar cane, the world's largest exporter of sugar cane, and is one of the world's largest consumers of sugar cane (fifth in the world). From its sugar cane, Brazil produces not only refined sugar but also anhydrous and hydrous alcohol mainly used as a blend in domestically-consumed gasoline.

The Brazilian government is also highly involved in its sugar-cane market. Blend rates of alcohol to gasoline are dictated to the market by law or decree, and this policy has a direct affect on producer and consumer welfare not only in Brazil but in the world. Recently the Brazilian government has increased the required blend rate from $20 \%$ to a current rate of $26 \%$. This action affects Brazilian producer prices for sugar cane, consumer prices for sugar and alcohol, and quantities both produced and consumed in Brazil. Further, it affects world prices for refined sugar as a portions of Brazil sugar exports will be diverted into alcohol production and consumption.

In this chapter, we first discuss the sugar market in Brazil. We do so in terms of raw and refined sugar, anhydrous and hydrous alcohol, government policies towards sugar cane and products made from it, and sugar and ethanol prices in Brazil and in the

world market. To investigate the potential effects of increasing alcohol-gasoline blending rates from $20 \%$ to $26 \%$, we develop a conceptual model that considers the Brazilian sugar cane market in the context of sugar cane production and prices, refined sugar production and prices, ethanol production and prices, and world market effects. The model also 
enables us to identify welfare measures for Brazilian and world consumers and producers of sugar-cane-based products. Next, we simulate an empirical model based on several measures of supply and demand sensitivities to prices and government policies and calculate ranges for the effects of the increased blending rates on prices, quantities, and welfare. Finally, conclusions are drawn.

\section{Raw and Refined Sugar}

Sugar is produced in two distinct regions in Brazil. The Center-South region is characterized by highly productive soil and excellent growing conditions and is one of the lowest cost growing areas in the world. Producers in this region are able to produce sugar at a cost that is under six cents per pound. The North-Northeast region has production in the coastal areas, is prone to periodic drought, and is characterized by generally low yields and high costs due to poor soil and to terrain that does not lend itself well to mechanized harvesting. Table 1 provides data regarding sugarcane area harvested and produced by region from 1990/91 through 2001/02. The area harvested in the NorthNortheast has decreased over the last 10 years and has been accompanied by variable levels of production. On the other hand, the area harvested and quantity produced in the Center-North has increased by more than 50 percent over that same period.

Brazil is the world leader in sugarcane production. Data regarding the major sugar producers and consumers in the world for 1998/99 are provided in Table 2. Brazil, EU, and India are the top three sugar producers in the world. Brazil produced 19.07 million metric tonnes (mmt) of sugar in 1998/99. Brazil also ranks among the top five in sugar consumption, consuming $9.45 \mathrm{mmt}$ of sugar in 1998/99. The largest consumer of sugar is India at $16.5 \mathrm{mmt}$, followed by the European Union at $14.4 \mathrm{mmt}$. 
Brazil is also the largest sugar exporter in the world. Data regarding the major sugar exporters and importers in the world for 1998/99 are provided in Table 3. Brazil dominates the export market, exporting roughly $8.9 \mathrm{mmt}$ of sugar, followed by the EU at $5.2 \mathrm{mmt}$ and Australia at $4 \mathrm{mmt}$. The largest sugar importer in the world is the Former Soviet Union (FSU) which imported $5.18 \mathrm{mmt}$ of sugar in 1998/99. The rest of the topfive sugar importers in the world are EU, Indonesia, U.S. and Japan.

Brazil exports both raw and refined sugar, as well as ethanol produced by processing sugarcane. The volume of raw sugar exported by the major raw-sugar exporters from 1990/91 through 1997/98 is provided in Table 4. Brazilian raw-sugar exports increased nearly six-fold from 1990/91 to 1997/98, while Australian raw-sugar exports doubled over that same period. Raw-sugar exports from the EU and Thailand experienced moderate growth, while Cuban raw-sugar exports decreased by two-thirds, down from $6.8 \mathrm{mmt}$ in 1990/91 to only $2.3 \mathrm{mmt}$ in 1997/98.

The volume of refined sugar exported by the major exporters is provided in Figure 1. The EU is by far the largest exporter of refined sugar, followed by Brazil, Thailand, and Ukraine. In 1995, roughly half the world sugar was exported in refined form. In 1996, only 40 percent of world exports were in the form of refined sugar. Exports of refined sugar from Brazil increased from $0.7 \mathrm{mmt}$ in 1991 to $3.6 \mathrm{mmt}$ in 1998 . Direct white processing, a controversial practice that can distort world sugar markets, gives the Brazilian sugar industry high flexibility and competitive advantages over other countries (Castellanos and Alvarez, 1999). Many producers in Brazil can now reach both raw and refined sugar markets with the same level of quality. 


\section{Ethanol Derived from Sugarcane}

While Brazil is the largest producer of raw and refined sugar in the world, most of its sugarcane is actually used to produce ethanol. A large portion of sugarcane production in Brazil (as high as 64 percent in 1997/98) goes towards the production of fuel (anhydrous and hydrous) alcohol, while the remaining portion goes towards the creation of raw or refined sugar. Anhydrous alcohol in Brazil is used to blend with gasoline as mandated by the Brazilian government. This program is similar to U.S. policy, with the exception that ethanol produced in the U.S. is derived from corn while ethanol produced in Brazil is derived from sugar (Schmitz and Polopolus, 1999). Hydrous alcohol in Brazil is used as fuel for vehicles that are powered by $100 \%$ alcohol. The number of vehicles powered by hydrous alcohol has declined sharply over the years. However, these vehicles still exist due to the subsidies provided by the Brazilian government for rental cars, taxis, and some government vehicles powered by hydrous alcohol.

Data regarding fuel-alcohol production by type and region from 1990/91 through 2001/02 are provided in Table 5. Hydrous-alcohol production in both regions has declined by more than 50 percent over the last ten years. However, anhydrous-alcohol production has increased more than five-fold over that same period. Technological innovations have led to a substantial increase in the volume of ethanol that can be produced per hectare of sugarcane. The increase in the yield of ethanol from 1975 through 1999 is illustrated in Figure 2. In 1999, roughly 5,500 liters were produced per hectare, while in 1975 the yield was only approximately 2,000 liters per hectare. This 
represents almost a three-fold increase in the efficiency of ethanol produced from sugarcane in Brazil. Brazil exports between 0.5 and 1.0 billion liters of ethanol per year.

\section{Government Policies affecting the Brazilian Sugar Industry}

Prior to 1998, the Brazilian sugar industry was highly regulated. The Institute of Sugar and Alcohol (IAA) was created in 1933 in order to solve a serious over production problem. The IAA essentially acted as a State Trading Enterprise that set production quotas and fixed prices in order to control the volume of exports. Brazil also had import tariffs and export taxes placed on sugar to ensure that alcohol-production targets were met.

The Brazilian National Alcohol Program (Proalcool) was created in 1975 as a response to the oil crisis of 1973 . Under this arrangement, the IAA purchased anhydrousalcohol at an equivalency rate of 44 liters of alcohol per $60 \mathrm{~kg}$ bag of sugar. Credit guarantees and low-fixed interest-rate subsidies were also provided for the construction of distilleries adjacent to sugar mills as well as autonomous plants. In 1979, the price of hydrous-alcohol-powered vehicles was set at 65 percent of the equivalent price for gasoline-powered vehicles and taxes for these vehicles were also set below those for gasoline-powered vehicles. Furthermore, gas stations were allowed to supply alcohol for alcohol-powered vehicles all weekend, whereas gas stations were closed for gasolinepowered vehicles on the weekend. Petrobas, the state oil company, controlled ethanol distribution. 
There were major policy changes in 1998. The monopoly enjoyed by Petrobas was removed. Ethanol prices were liberalized on February 1, 1999 and subsidies paid to hydrous-alcohol producers were reduced from 0.98 reals per liter to 0.45 reals per liter. (USDA, Sugar and Sweetener Situation and Outlook, 2001). Subsidies paid to anhydrous-alcohol producers were eliminated. Currently, ethanol production is regulated by government decree. Each year, a Presidential Decree sets a range (currently 20 to 24 percent) for the percentage of ethanol that must be used in gasoline. In May 2001, the Brazilian government raised the mandated alcohol content in gasoline from 20 percent to 22 percent. In January 2002, the government again raised the mandated blending ratio of anhydrous alcohol with gasoline from 22 to 24 percent. The government tends to increase the blending ratio when gasoline prices are high and sugar prices are low and tends to decrease the blending ratio when gasoline prices are low.

While Brazil is now less dependent on imported oil, domestic oil resources have begun to be developed over the past twenty years. The long-run validity of the alcoholfuels strategy can be seen in the unexpected rise in oil prices from $\$ 18$ per barrel in January 2002 to $\$ 26$ per barrel in April 2002 because of tensions in the Middle East, the primary supplier of oil to Brazil as well as the United States. The sugar and fuel-alcoholproducing industry is currently lobbying the government to raise the blend to 26 percent for the 2002/03 marketing year. However, the current law states that the mix be limited to 24 percent. Moreover, Brazil's auto industry is reportedly reluctant to advocate the change due to technical reservations about raising the mix limit.

Since 1998, there have been other policy changes that have affected the Brazilian sugar sector. A common external tariff of 20 percent on sugar imports was established in 
2001. Imports of ethanol are taxed at 30 percent. This policy is in place to make sure that sugar and ethanol producers receive a higher price for their product, without facing competition from other low-cost exporters with respect to the domestic market. However, there is no tax on intra-zone trade of ethanol for Brazil's MERCOSUR partners. Finally, there still remains a support mechanism that compensates for sugarcane-cost differentials across regions that is well under the "de minimis" clause of the WTO agricultural agreement.

\section{Sugar and Ethanol Prices}

Prior to 1998, the government set the price paid to independent growers of sugarcane in Brazil. With the removal of government price setting, Sao Paulo producers, the largest producers in Brazil, set up a model-cane-payment system regulated by the Sao Paulo State Sugarcane, Sugar and Alcohol Producers' Council (CONSECANA-SP). The formula for calculating the grower price of cane is based on the following four criteria:

1. Quality of each grower's cane expressed in terms of recoverable total sugar;

2. The average Sao Paulo state price for sugar and alcohol, FOT at the mill as surveyed by the University of Sao Paulo, College of Agriculture in Piracicaba (ESALQ);

3. The mix of products (sugar, anhydrous and hydrous alcohol) at each mill; and

4. The sugarcane share of the total cost of sugar and alcohol at the state level. Monthly prices received for refined sugar, anhydrous alcohol, and hydrous alcohol from January 1999 through March 2002 are provided in Figure 3. The prices in this Figure have been converted from data provided by ESALQ to U.S. dollars using monthly 
exchange rates provided by the Federal Reserve Bank of St. Louis (http://www.stls.frb.org/fred/data/exchange/EXBZUS). Refined-sugar prices in Brazil reached as low as 4.59 cents/lb in June 1999 , but climbed to a peak of 12.75 cents/lb by August 2000. The price of refined sugar in Brazil was 8.23 cents/lb in March 2002. The internal prices for both anhydrous and hydrous alcohol have followed a similar trend over this time period. The price of anhydrous alcohol was 25.94 cents/liter in March 2002, while the price of hydrous alcohol was 30.02 cents/liter.

The average world-raw-sugar price and the average price received for sugarcane by farmers in Brazil from 1985/86 through 2000/01 are depicted in Figure 4. The average world raw sugar price has been converted to US cents per pound, while the price received for sugarcane by producers has been converted to U.S. dollars per tonne. The world-rawsugar price increased dramatically from 1985/86 through 1989/90 and reached its peak of 13.44 cents per pound in 1995/96. The price dropped to as low as 6.54 cents/lb in 1999/00. The average price received for sugarcane by producers in Brazil reached its peak in 1996/97 of 14.44 dollars per tonne. It dropped to as low as 6.79 dollars per tonne in 1999/00. Although not shown in Figure 3, the futures price for world-raw sugar in the first quarter of 2002 is just over six cents per pound reflecting weak growth in global demand and concern over the record crop expected in Brazil in 2002.

\section{Selling Sugar at the World Price}

Questions have arisen as to the meaning of the world price of sugar in the context of sugar marketing. As shown in Figure 4, world-sugar prices (refined) dipped below U.S. 10 cents per pound in 1999. How much of Brazilian sugar is sold at that price is not 
presented here. However, in aggregate terms, sugar specialist have calculated that around only 15 percent of all world-sugar production is traded in the so-called free-world-sugar market (Alvarez and Castellanos, 1995: p54). For Brazil, the percentage appears to be much higher than this.

Brazil obtains certain preferential treatment from key sugar importers. For example, consider U.S. sugar imports under tariff-rate quota (TRQ) by country from 1995/96 through 2000/01 under the WTO. The top-ten exporters of sugar to the U.S. over this time period are provided in Table 6. The Dominican Republic is the largest exporter of sugar to the U.S., receiving 185,346 $\mathrm{mt}$ of the TRQ allotment. However, Brazil receives the second largest allotment of the U.S. TRQ $(152,700 \mathrm{mt})$. These exports by Brazil to the U.S. are priced at the U.S. internal sugar price, which, in 1999, was at least three times higher than world market prices. Note however, that Brazilian exports to the United States under the TRQ are a very small part of total Brazilian exports. Because of the nature of the U.S. sugar quota, most of the sugar has to enter the United States in raw form. However, the largest percentage of Brazilian exports are in refined form.

\section{Theoretical Model of the Implications of Higher Ethanol Blend Rates}

The Brazilian government is currently exploring the possibility of raising the blend rate for anhydrous alcohol in gasoline from 24 percent to 26 percent. This increase is being considered even though Brazil recently increased the blend rate from 20 to 22 percent and then again to 24 percent. This decision comes in the wake of increased oil prices caused by the unstable situation in the Middle East. It would be interesting to 
determine what the effects of higher ethanol blend rates in Brazil are on sugarcane producers, sugar processors, anhydrous alcohol processors, hydrous alcohol processors, and foreign sugar consumers. First, we describe a theoretical model to capture these effects, and then we obtain empirical results for an increase in the blend rate from 20 percent to 26 percent.

Both domestic and foreign sugar markets facing Brazil are depicted in Figure 5. Consider the initial situation that Brazil was in less than two years ago, when the blend rate for anhydrous alcohol was set at 20 percent. $\mathrm{D}_{\mathrm{a}}{ }^{0}$ represents the sugarcane demand for anhydrous alcohol. The aggregate domestic demand curve for sugarcane $\left(\mathrm{D}_{\mathrm{c}}{ }^{0}\right)$ is comprised of the horizontal sum of the demand for anhydrous alcohol $\left(\mathrm{D}_{\mathrm{a}}{ }^{0}\right)$, the demand for hydrous alcohol (not depicted), and the demand for cane used to produce sugar (also not shown). The aggregate supply of sugarcane is represented by $S_{c}$ in Figure 5. The initial excess supply and demand curves for sugar $\left(\mathrm{ES}_{\mathrm{s}}{ }^{0}\right.$ and $\left.\mathrm{ED}_{\mathrm{s}}\right)$ are shown in the right panel of Figure $5 . \mathrm{ED}_{\mathrm{s}}$ actually begins at point $c$, moves to point $d$, is discontinuous at this point and then moves along the solid line $\left(\mathrm{ED}_{\mathrm{s}}\right)$ in the right panel. The excess demand curve is comprised of the demand for sugar in the U.S. (at a fixed TRQ price equal to $\mathrm{P}_{\mathrm{s}}^{\mathrm{US}}$ ) and the demand for sugar from the rest of the world (ROW).

The excess supply curve for Brazilian sugar $\left(\mathrm{ES}_{\mathrm{S}}{ }^{0}\right)$ is derived from the domestic supply and demand curve for cane, but the intercept of the excess supply curve is higher than what would be the case if the right panel represented sugarcane. This is because the demand in the foreign sugar market is for refined sugar. Hence, all prices and quantities in that market must be converted into sugarcane equivalent form. The difference between $\mathrm{P}_{\mathrm{w}}{ }^{0}$ (the equilibrium price of refined sugar in sugarcane equivalent form) and $\mathrm{P}_{\mathrm{c}}{ }^{0}$ (the 
equilibrium price of sugarcane in the domestic market) is the processing and handling cost of getting sugarcane to the foreign market in refined form. In the face of a low blending rate, sugar exports (in sugarcane equivalent form) are represented by $\mathrm{X}^{0}$, and $\mathrm{Q}_{\mathrm{d}}{ }^{0}$ is the aggregate domestic demand for sugarcane from all four sources. Under this scenario, sugarcane producer surplus equals the area, $P_{c}^{0} b o+c d e f$. Consumer surplus is comprised of domestic sugar processor surplus, anhydrous alcohol surplus, hydrous alcohol surplus, and foreign sugar surplus and can be measured as long as consumption is kept in sugarcane equivalent form. Aggregate domestic consumer surplus is equal to area $P_{c}^{0} i j$ in Figure 5. Measures of consumer surplus for individual sectors can also be calculated, but are not shown. ROW welfare from trading with Brazil is equal to area $\mathrm{klm}$ in the right panel of Figure 5.

The welfare implications for an increase in the blend rate of anhydrous alcohol in gasoline are also depicted in Figure 5 where the domestic demand for anhydrous alcohol shifts outwards from $\mathrm{D}_{\mathrm{a}}{ }^{0}$ to $\mathrm{D}_{\mathrm{a}}{ }^{1}$ causing the aggregate demand curve for sugarcane to shift from $\mathrm{D}_{\mathrm{c}}{ }^{0}$ to $\mathrm{D}_{\mathrm{C}}{ }^{1}$ in the left panel. This causes the excess demand curve to shift to $\mathrm{ES}_{\mathrm{S}}{ }^{1}$ and results in an equilibrium world price for sugar (in sugarcane equivalent form) equal to $\mathrm{P}_{\mathrm{w}}{ }^{1}$. Brazil exports $\mathrm{X}^{1}$ and domestic production is increased to $\mathrm{Q}_{\mathrm{s}}{ }^{1}$. Producer surplus is now equal to the area, $P_{c}{ }^{1} a o+c d h g$, and aggregate domestic consumer surplus equals the area $P_{c}{ }^{l} s r$. ROW welfare from trading with Brazil is equal to area hnm in the right panel of Figure 5 .

Comparing producer and consumer welfare yields the following results. The change in producer surplus is equal to the area, $\mathrm{P}_{\mathrm{c}}{ }^{1} \mathrm{baP}_{\mathrm{c}}{ }_{\mathrm{c}}$-efhg. This amount is always positive since area $P_{c}{ }^{l} b a P_{c}{ }^{0}>e l n g>e f h g$. Hence, producers always gain. The change 
in aggregate domestic consumer surplus is equal to the area, $P_{c}{ }^{1} s r-P_{c}{ }^{0} i j$, which can be either positive or negative depending upon relative elasticities. Finally, the ROW loses area elng due to higher export prices and lower exports.

\section{Empirical Results Associated with Higher Blend Rates}

The above theoretical model can be used in order to run a counterfactual simulation that will show what the market structure will look like if the blend rate for anhydrous alcohol is increased to 26 percent in the future. In order to derive our simulation results, we assume linear supply, demand, and excess demand curves. We use the three-year average, 1998/99-2000/01, as a benchmark for our simulation. While the blend rate did fluctuate somewhat over this time period, it is assumed that the blend rate was 20 percent. The simulation is run using three different sets of values for the price elasticity of domestic sugarcane demand, the price elasticity of domestic sugarcane supply, and the price elasticity of excess demand for sugar in the ROW. These elasticities represent a wide range of possible parameters over which the true outcome will most likely be contained. The three-year average U.S. sugar price over this period was 20.51 cents/pound. This number, along with the average TRQ of 152.7 metric tonnes (MT), is used for both the base case and the simulation.

In order to obtain estimates of welfare effects, it is necessary to convert all values to sugarcane equivalent form. This is accomplished using data regarding the percentage of sugarcane used for sugar production vs. the percentage used for anhydrous and hydrous alcohol. Taking the three-year average values for production of these three different products made from sugarcane and converting them to sugarcane equivalent 
form, the following conversion rates are calculated and assumed to remain fixed from the base period to the simulation period. The conversion rate for sugar with respect to sugarcane is $13.39 \%$ in similar units. This can be interpreted to mean that one MT of sugarcane yields approximately 133.9 Kilograms of sugar. The conversion rate for alcohol with respect to sugarcane is computed by aggregating anhydrous and hydrous alcohol. The conversion rate turns out to be $7.95 \%$ in 1000 Liters/MT. This can be interpreted to mean that one MT of sugarcane is used in the production of 79.5 liters of alcohol. All quantities for all sugarcane uses are converted to sugarcane equivalent form using these rates of conversion. The sugarcane price received by farmers is in sugarcane equivalent form. However, as a point of reference, the change in the world sugar price is converted back to refined sugar form by inverting the aforementioned conversion rate.

Welfare estimates obtained from simulating an increase from 20 percent anhydrous alcohol blend in gasoline to 26 percent are provided in Table 7 . The results in Table 7 are divided into three scenarios representing three different sets of elasticity parameters. The low sensitivity case is associated with initial values for the demand elasticity equal to -0.5 , a supply elasticity equal to 0.5 , and an excess demand elasticity equal to -2.0 . The medium sensitivity case is associated with initial values for the demand elasticity equal to -1.0 , a supply elasticity of 1.0 , and an excess demand elasticity of -5.0 . The high sensitivity case is associated with a demand elasticity of -2.0 , supply elasticity of 2.0 , and excess demand elasticity equal to -20 . The first column associated with each scenario gives the absolute difference between a 26 percent blend rate and a 20 percent rate. The second column associated with each scenario indicates the percentage change associated with increasing the blend rate from 20 to 26 percent. All 
prices are converted to U.S. dollars using exchange rate data. Prices and quantities are given in sugarcane equivalent form.

An increase in the blend rate from 20 to 26 percent causes the price received by farmers for sugarcane to rise between 4 and 11 percent. This causes the world price for refined sugar to increase by between $\$ 3.04$ and $\$ 7.58$ per metric tonne. Anhydrous alcohol consumption increases by between 21 and 34 percent, while the quantity of cane used for domestic sugar and the quantity of cane used for the production of hydrous alcohol both increase by between 3 and 14 percent. The increase in the world price of sugar causes Brazilian sugar exports to drop by between 8 and 34 percent. Producers receive higher prices due to expanded demand for sugar, and production rises by between 5 and 8 percent.

The consumer surplus associated with sugar processors, anhydrous alcohol processors, and hydrous alcohol producers are also provided in Table 7. Note that these sectors are technically consumers in this model because they are the ones purchasing the sugarcane from producers. Anhydrous processor surplus increases from between 33 and 61 percent due to the increase in the blend rate for anhydrous alcohol (ethanol) used in gasoline from 20 to 26 percent. Both sugar and hydrous alcohol producers gain 13 to 37 percent in consumer surplus. In addition, producer surplus increases by between 11 and 17 percent, representing an increase of between $\$ 125$ and $\$ 306$ million in producer welfare. Finally, aggregate welfare in the Brazilian sugar sector increases by between \$372 and \$728 million if the blend rate is increased from 20 to 26 percent. Of course, this number does not include the substantial losses in welfare accruing to crude oil producers, crude oil importers, and the like from this government policy. 


\section{Conclusions}

Brazil has a keen interest in pushing toward freer trade in sugar. The average world price for sugar during the 1984/85 - 1994/95 period was 9.46 US cents per pound. The average world-production cost was 18.04 cents per pound (source: LMC International Ltd., Oxford, England). Experts claim that Brazilian producers are still able to make money at this average world price. However, world prices dipped to below 7 cents per pound during the 1999 period. Whether it is profitable to produce and sell sugar at this price is not investigated here. However, there is general agreement that Brazil would experience significant gains with freer trade in sugar. In a world of free trade in sugar, world prices would range between 16 and 20 cents per pound US\$ (Schmitz, 1995). If this were the case, Brazilian producers stand to gain in the neighborhood of $\$ 2.6$ billion US per year (Borrell and Pearce, 1999). This is due to the large production volume in Brazil combined with its being a low-cost producer.

Over the long-run, the direction of Brazil's sugar and fuel-alcohol industry will pivot on a number of key variables such as the relative attractiveness of sugar cane agriculture in the Center-South, both in terms of costs of production and returns from alternative crops. Another important variable will be the growth trend in sugar consumption to be largely determined by population and income growth and expansion in the industrial use of sugar which tends to mirror development of a consumer style economy such as in the US and Western Europe. The vitality of the world-sugar market is also a leading variable, one that Brazil will be influenced by as well as play a role as a price setter. The track record of the Brazilian sugar production and distribution sector 
over the past decade is impressive. Owing to its low cost of production, currently estimated at under- 6 cents a pound in the Center-South, there is no reason to doubt that Brazil will be a leading factor in the world-sugar market in the years ahead.

Perhaps the overarching variable is the level of commitment of the Brazilian government to the fuel-alcohol program. The Cardoso government has repeatedly stated that it will continue to promote alcohol as a strategic source of energy and as a means to help fight polution. It is unlikely that this policy will change radically with subsequent governments in Brasilia. The government is also likely to continue to engage in stocking policies to insure that sufficient product is available to meet the needs of the country and to even out prices.

The trend toward greater use of anhydrous alcohol is expected to continue while the contraction in hydrous demand is also likely as the public is wary of purchasing a hydrous-alcohol vehicle dependent solely on the availability of hydrous fuel. As technologies are developed, the long awaited use of alcohol in diesel engines is expected to supplement the current concentration in use in passenger vehicles and give a boost to fuel-alcohol demand.

Looking forward, some advocates of fuel alcohol in Brazil foresee the development of a substantial export market. Currently only about 0.5 to 1.0 billion liters of production are exported annually. To help promote globalization of ethanol, Brazil is currently providing information on the economics and technological aspects of ethanol production and trade worldwide. 
Table 1 Brazil: Sugar cane Area Harvested and Production by Regions

\begin{tabular}{llllllll} 
& \multicolumn{2}{c}{ Center-South } & \multicolumn{2}{c}{ North-Northeast } & \multicolumn{2}{c}{ Brazil Total } \\
\cline { 2 - 8 } Year & $\begin{array}{l}\text { Area } \\
\text { Harvested Production Harvested Production Harvested } \\
\text { (mil ha) }\end{array}$ & $\begin{array}{c}\text { Cane } \\
\text { (mil tons) }\end{array}$ & $\begin{array}{l}\text { Area } \\
\text { (mil ha) }\end{array}$ & $\begin{array}{l}\text { Cane } \\
\text { (mil tons) }\end{array}$ & $\begin{array}{l}\text { Canea } \\
\text { (mil ha) }\end{array}$ & $\begin{array}{l}\text { Production } \\
\text { (mil tons) }\end{array}$ \\
\hline 1990/91 & 2.47 & 170.0 & 1.07 & 51.8 & 3.54 & 221.8 \\
$1991 / 92$ & 2.48 & 178.7 & 1.02 & 49.8 & 3.50 & 228.5 \\
$1992 / 93$ & 2.41 & 176.0 & 0.95 & 47.8 & 3.36 & 223.8 \\
$1993 / 94$ & 2.51 & 184.1 & 0.86 & 33.3 & 3.36 & 217.4 \\
$1994 / 95$ & 2.62 & 196.3 & 0.95 & 46.0 & 3.57 & 242.3 \\
$1995 / 96$ & 2.77 & 204.4 & 0.97 & 47.0 & 3.77 & 251.4 \\
$1996 / 97$ & 3.14 & 231.4 & 1.17 & 55.0 & 4.31 & 286.4 \\
$1997 / 98$ & 3.31 & 249.7 & 0.99 & 51.0 & 4.29 & 300.7 \\
$1998 / 99$ & 3.59 & 269.5 & 0.79 & 38.8 & 4.39 & 308.3 \\
$1999 / 00$ & 3.53 & 264.0 & 0.75 & 35.0 & 4.65 & 305.0 \\
$2000 / 01$ & 3.87 & 227.0 & 0.78 & 39.0 & 4.65 & 256.5 \\
$2001 / 02$ & 3.77 & 244.0 & 0.78 & 48.0 & 4.55 & 292.0 \\
$20002 / 02^{*}$ & 3.80 & 288.0 & 0.80 & 52.0 & 4.60 & 340.0 \\
\hline
\end{tabular}

${ }^{*}$ Forecast JOB Economia and Peter Buzzanell \& Associates, Inc.

Source: U.S. Department of Agriculture, history. 
Table 2. Major Sugar Producers and Consumers 1998/99

\begin{tabular}{lc|lc}
\hline \multicolumn{2}{c|}{ Production } & \multicolumn{2}{c}{ Consumption } \\
\hline Country & $\begin{array}{c}\text { (mmt raw } \\
\text { value) }\end{array}$ & Country & $\begin{array}{c}\text { (mmt raw } \\
\text { value) }\end{array}$ \\
\hline Brazil & 19.07 & India & 16.50 \\
EU* & 17.90 & EU* $^{*}$ & 14.40 \\
India & 16.20 & Brazil & 9.45 \\
China & 8.80 & FSU** & 9.38 \\
United States & 7.40 & United States & 9.00 \\
Thailand & 5.27 & China & 8.37 \\
Australia & 5.25 & Mexico & 4.10 \\
Mexico & 5.05 & Pakistan & 3.24 \\
FSU** & 3.85 & Indonesia & 3.24 \\
Pakistan & 3.67 & Japan & 2.40 \\
\hline
\end{tabular}

* European Union

** Former Soviet Union

Table 3. Major Sugar Exporters and Importers, 1998/99

\begin{tabular}{lc|lc}
\hline \multicolumn{2}{c|}{ Exports } & \multicolumn{2}{c}{ Imports } \\
\hline Country & $\begin{array}{c}(\mathrm{mmt} \text { raw } \\
\text { value })\end{array}$ & Country & $\begin{array}{c}\text { (mmt raw } \\
\text { value) }\end{array}$ \\
\hline Brazil & 8.85 & FSU** & 5.18 \\
EU* & 5.23 & EU* & 1.98 \\
Australia & 4.03 & Indonesia & 1.67 \\
Thailand & 3.36 & United States & 1.67 \\
Cuba & 2.40 & Japan & 1.52 \\
South Africa & 1.23 & Korea & 1.27 \\
Guatemala & 1.20 & Iran & 0.98 \\
Mexico & 0.94 & Malaysia & 0.89 \\
Colombia & 0.87 & Egypt & 0.80 \\
Pakistan & 0.60 & Nigeria & 0.70 \\
\hline
\end{tabular}

* European Union

** Former Soviet Union 
Table 4. Major Sugar Exporters, Selected Years.

\begin{tabular}{lccc}
\hline Country & \multicolumn{3}{c}{ Exports, Million Metric Tonnes } \\
\hline Cuba & $1990-91$ & $1993-94$ & $1997-98$ \\
EU* & 6.8 & 3.5 & 2.3 \\
Thailand & 5.6 & 6.3 & 6.2 \\
Brazil & 2.7 & 2.8 & 2.9 \\
Australia & 1.3 & 2.3 & 7.2 \\
Total & 2.8 & 3.5 & 4.6 \\
\hline
\end{tabular}

Source: ERS, several issues.

*European Union

Table 5. Fuel Alcohol (Ethanol) Production by Type and by Region in Brazil

\begin{tabular}{|c|c|c|c|c|c|c|c|c|c|}
\hline \multirow[b]{2}{*}{ Year } & \multicolumn{2}{|c|}{ Center-South } & \multicolumn{3}{|c|}{ Billion Liters } & \multicolumn{3}{|c|}{ Brazil } & \multirow[b]{2}{*}{ Total } \\
\hline & $\begin{array}{c}\text { Anhydrous } \\
\text { Alcohol }\end{array}$ & $\begin{array}{l}\text { Hydrous } \\
\text { Alcohol }\end{array}$ & Total & $\begin{array}{c}\text { Anhydrous } \\
\text { Alcohol }\end{array}$ & $\begin{array}{l}\text { Hydrous } \\
\text { Alcohol }\end{array}$ & Total & $\begin{array}{c}\text { Anhydrous } \\
\text { Alcohol }\end{array}$ & $\begin{array}{l}\text { Hydrous } \\
\text { Alcohol }\end{array}$ & \\
\hline 1990/91 & 1.1 & 8.9 & 10.0 & 0.2 & 1.6 & 1.8 & 1.3 & 10.5 & 11.8 \\
\hline 1991/92 & 1.8 & 9.1 & 10.9 & 0.2 & 1.6 & 1.8 & 2.0 & 10.7 & 12.7 \\
\hline 1992/93 & 1.9 & 8.1 & 10.0 & 0.3 & 1.4 & 1.7 & 2.2 & 9.5 & 11.7 \\
\hline 1993/94 & 2.4 & 8.0 & 10.4 & 0.1 & 0.8 & 0.9 & 2.5 & 8.8 & 11.3 \\
\hline 1994/95 & 2.6 & 8.6 & 11.2 & 0.3 & 1.3 & 1.6 & 2.9 & 9.8 & 12.7 \\
\hline 1995/96 & 2.6 & 8.3 & 10.9 & 0.4 & 1.3 & 1.7 & 3.0 & 9.7 & 12.7 \\
\hline 1996/97 & 3.8 & 8.3 & 12.1 & 0.8 & 1.5 & 2.3 & 4.6 & 9.8 & 14.4 \\
\hline 1997/98 & 4.8 & 8.5 & 13.3 & 0.8 & 1.2 & 2.0 & 5.6 & 9.6 & 15.2 \\
\hline 1998/99 & 4.8 & 7.4 & 12.2 & 0.8 & 0.7 & 1.5 & 5.6 & 8.1 & 13.7 \\
\hline 1999/00 & 5.4 & 6.2 & 11.6 & 0.6 & 0.5 & 1.1 & 6.0 & 6.7 & 12.8 \\
\hline 2000/01 & 5.3 & 5.9 & 11.2 & 0.7 & 0.5 & 1.2 & 6.0 & 6.4 & 12.4 \\
\hline $2001 / 02^{*}$ & 5.5 & 4.6 & 10.1 & 1.0 & 0.4 & 1.4 & 6.5 & 5.0 & 11.5 \\
\hline $2002 / 03^{*}$ & 7.7 & 4.1 & 11.8 & 1.3 & 0.5 & 1.8 & 9.0 & 4.6 & 13.6 \\
\hline
\end{tabular}

* Estimate and forecast JOB Economica and Peter Buzzanell \& Associates, Inc. Source: FNP and United States Department of Agriculture, history 


\begin{tabular}{lc}
$\begin{array}{l}\text { Table 6. Top } 10 \text { Exporters of Sugar to the U.S. } \\
\text { under TRQs (1995/96-2000/01)* }\end{array}$ \\
\hline \multicolumn{2}{c}{ TRQs (raw value) } \\
\cline { 2 - 2 } Largest Exporters & Metric Tonnes \\
\hline Dominican Republic & 165,346 \\
Brazil & 152,700 \\
Philippines & 142,169 \\
Australia & 87,408 \\
Guatemala & 50,549 \\
Argentina & 45,283 \\
Peru & 43,177 \\
El Salvador & 27,381 \\
Columbia & 25,274 \\
South Africa & 24,221 \\
*TRQ represents tariff-rate quota. &
\end{tabular}

Source: Sugar and Sweetener Situation \& Outlook/SSS-232, September 2001 (page 40). 
Table 7: Welfare Effects of Higher Ethanol Blend Rates

For Anhydrous Alcohol Production in Brazil

Low Sensitivity

Absolute Percentage
Difference Difference
Medium Sensitivity

Absolute Percentage Absolute Percentage Difference Difference
Difference
Cane Price Received by Farmers (\$/MT)

World Sugar Price (\$/MT)

Cane Used for Domestic Sugar (mmt)

Cane Used for Anhydrous Alcohol (mmt)

Cane Used for Hydrous Alcohol (mmt)

Cane Exported as Sugar to ROW (mmt)

Total Cane Consumption (mmt)

Total Cane Production ( $\mathrm{mmt}$ )

Domestic Sugar Processor Surplus

Domestic Anhydrous Processor Surplus

Domestic Hydrous Processor Surplus

Aggregate Domestic Consumer Surplus

Domestic Producer Surplus

Aggregate Domestic Welfare

ROW Sugar Processor Surplus

$\begin{array}{rrrrrr}\$ 1.01 & 11 \% & \$ 0.65 & 7 \% & \$ 0.41 & 4 \% \\ \$ 7.58 & 4 \% & \$ 4.85 & 3 \% & \$ 3.04 & 2 \% \\ 2.2 & 3 \% & 4.4 & 7 \% & 9.4 & 14 \% \\ 15.8 & 21 \% & 18.6 & 25 \% & 25.1 & 34 \% \\ 3.0 & 3 \% & 5.8 & 7 \% & 12.5 & 14 \% \\ -5.5 & -8 \% & -8.7 & -14 \% & -21.9 & -34 \% \\ 21.1 & 9 \% & 28.7 & 13 \% & 46.9 & 20 \% \\ 15.6 & 5 \% & 20.0 & 7 \% & 25.1 & 8 \% \\ & & & & & \\ \$ 82 & 13 \% & \$ 64 & 20 \% & \$ 60 & 37 \% \\ \$ 230 & 33 \% & \$ 144 & 41 \% & \$ 109 & 61 \% \\ \$ 110 & 13 \% & \$ 85 & 20 \% & \$ 80 & 37 \% \\ \$ 422 & 19 \% & \$ 292 & 27 \% & \$ 248 & 45 \% \\ \$ 306 & 11 \% & \$ 197 & 14 \% & \$ 125 & 17 \% \\ \$ 728 & 14 \% & \$ 490 & 19 \% & \$ 372 & 29 \% \\ -\$ 63 & -16 \% & -\$ 39 & -25 \% & -\$ 22 & -56 \%\end{array}$

${ }^{*}$ Numbers represent numerical and corresponding percentage differences over the base case

${ }^{* *}$ Measures the difference when moving from a policy of a $20 \%$ blend rate to $26 \%$.

${ }^{* * *}$ All prices were converted to U.S. dollars

${ }^{* * * * A l l}$ welfare results are in millions of U.S. dollars.

Low Sensitivity Results use initial values of demand elasticity $=-0.5$, supply elasticity $=0.5$, and excess demand elasticity $=-2.0$

Medium Sensitivity Results use initial values of demand elasticity $=-1.0$, supply elasticity $=1.0$, and excess demand elasticity $=-5.0$

High Sensitivity Results use initial values of demand elasticity $=-2.0$, supply elasticity $=2.0$, and excess demand elasticity $=-20$ 


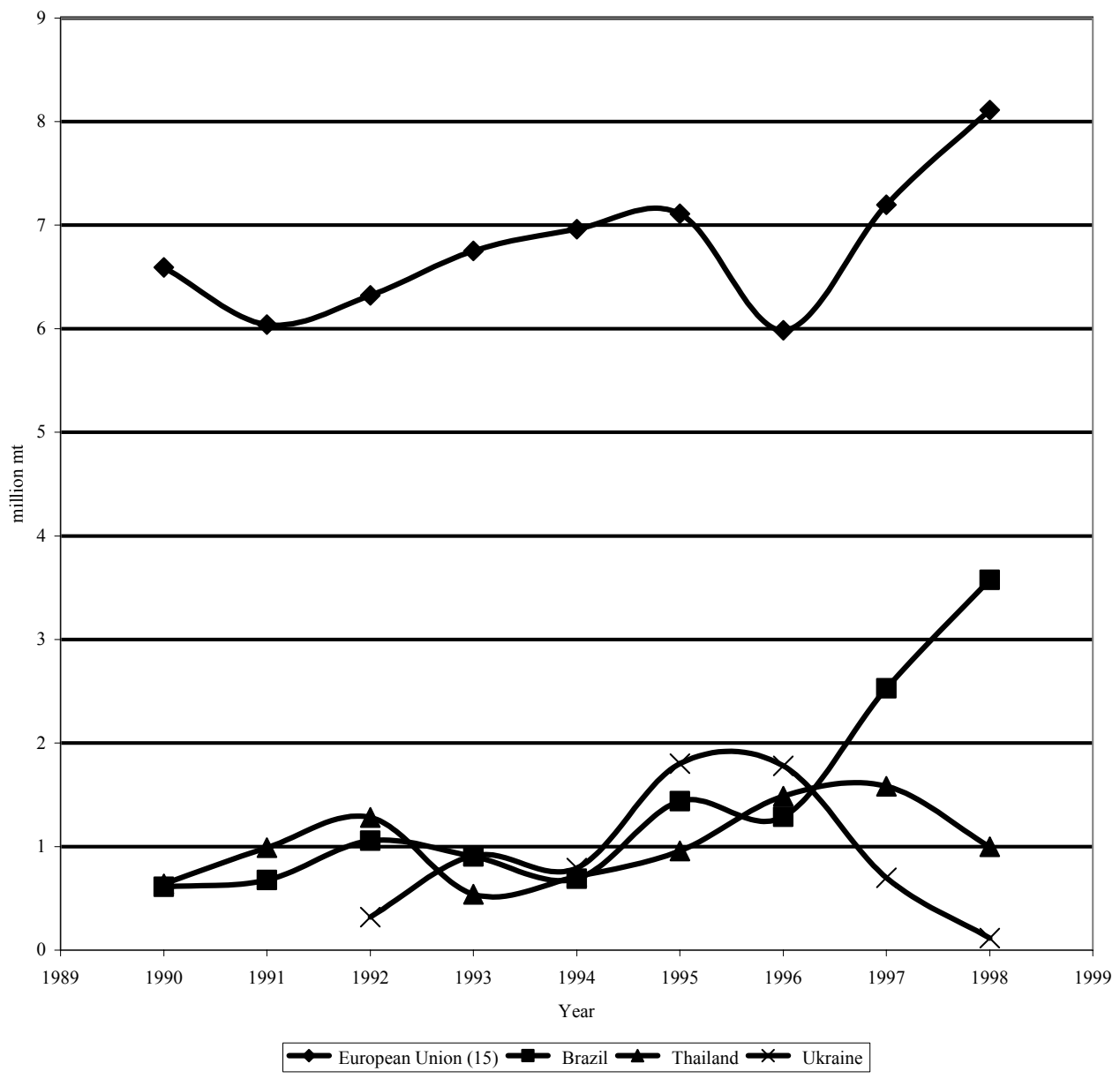

Figure 1. Exports of Refined Sugar by Major Exporters, 1990-1998 


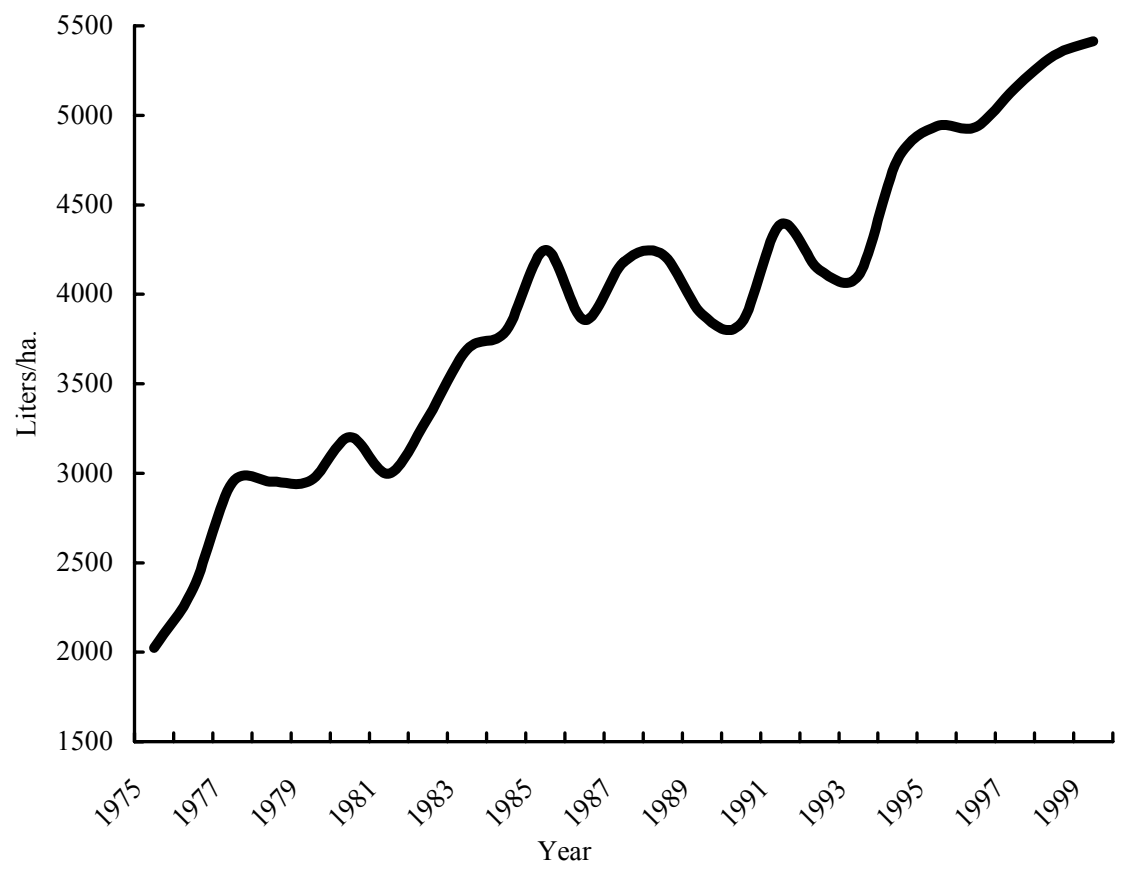

Figure 2. Yield of Ethanol from Sugarcane in Brazil in Liters per Hectare, (1975 1999) 


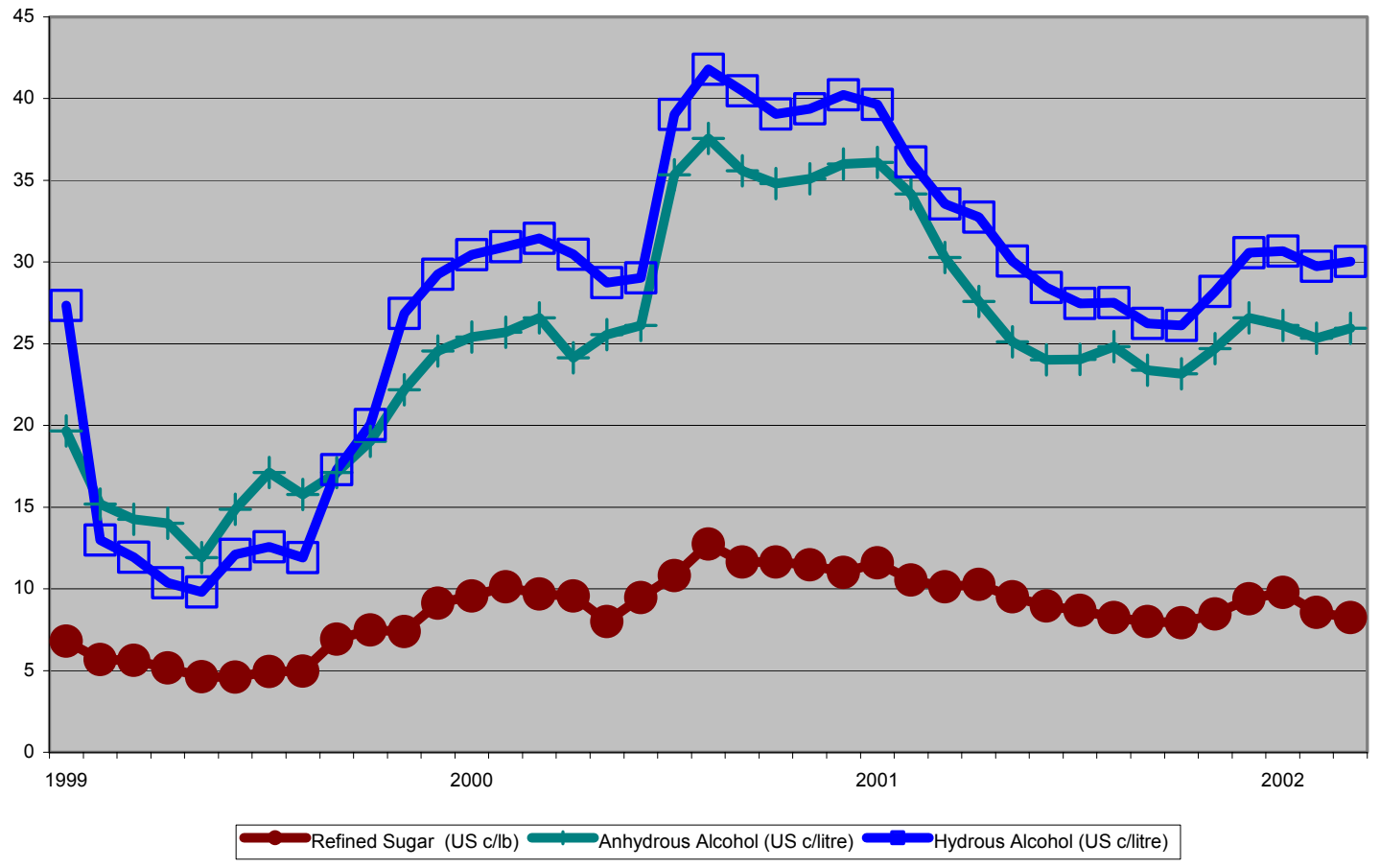

Figure 3. Prices for Refined Sugar, Anhydrous Alcohol, and Hydrous Alcohol in Brazil (January 1999 - March 2002) 


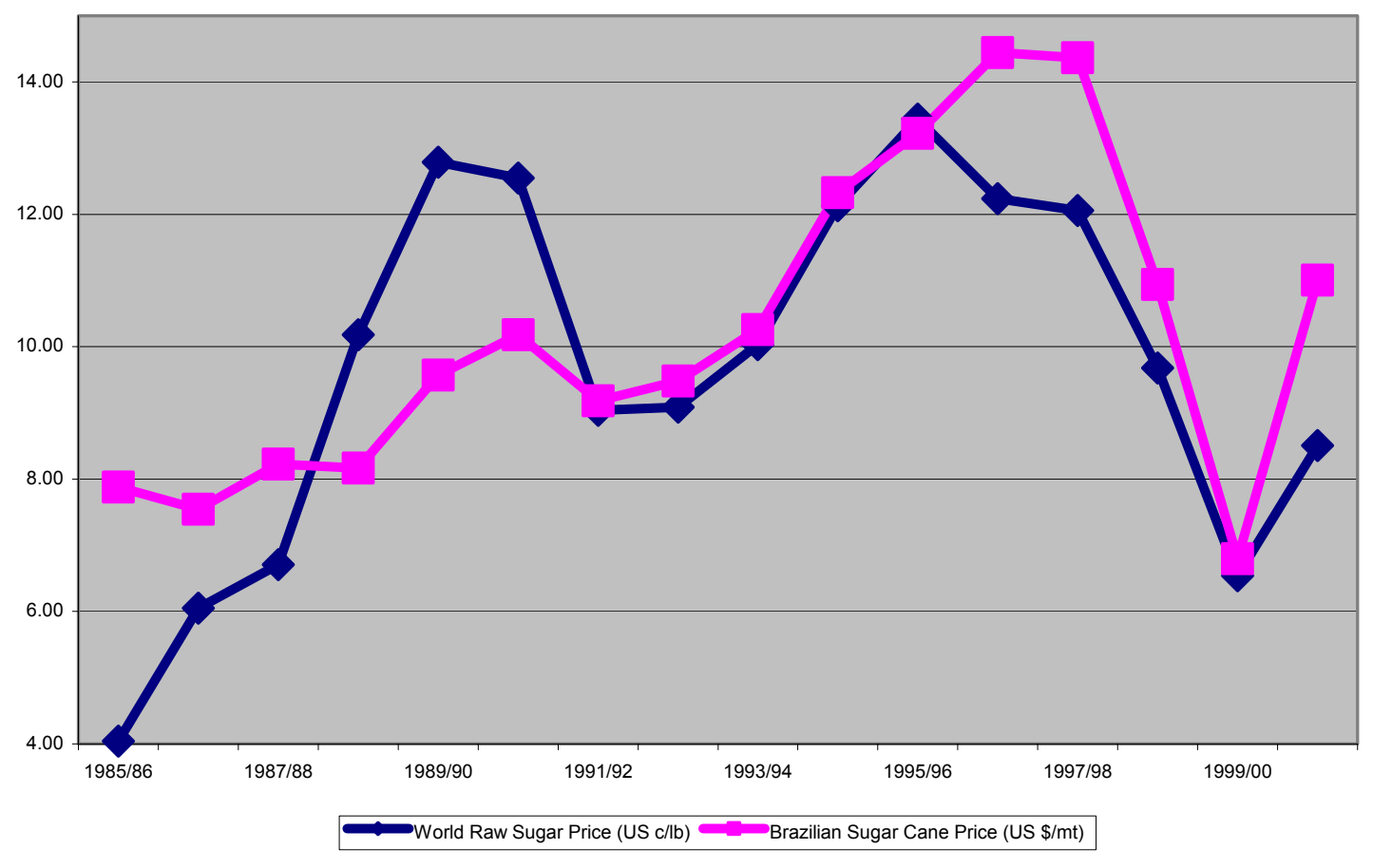

Figure 4. World Raw Sugar Prices vs. Sugar Cane Prices Received by Farmers in Brazil (1985/86-2000/01) 


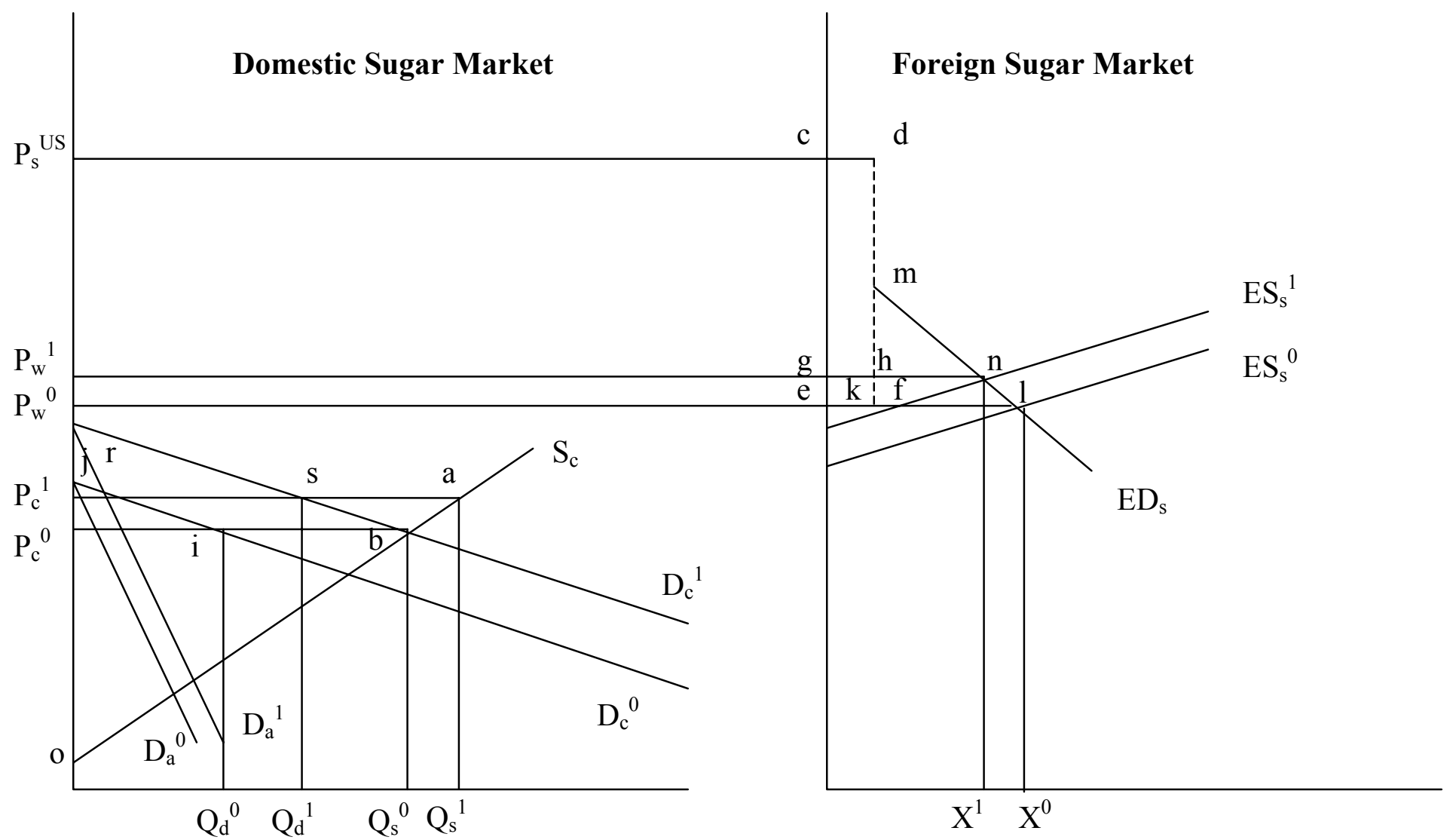

Figure 5. Theoretical Model of Effects of Higher Ethanol Blend Rates 


\section{References}

Alvarez, Jose and Lazaro Pena Castellanos. "Preliminary Study of the Sugar Industries in Cuba and Florida within the Context of the World Sugar Market." Gainesville, Florida: International Working Paper IW95-6, International Agricultural Trade and Development Center, Food and Resource Economics Department, Institute of Food and Agricultural sciences, University of Florida, March, 1995.

Borrell, Brent and David Pearce. "Sugar: The Taste Test of Trade Liberalization." Conference on Agriculture and New Trade Agenda from a Development Perspective, Geneva, Switzerland, October 1999.

Castellanos, Lazaro Pena and Jose Alvarez. "The Cuban Sugar Agroindustry and the International Sweeteners Market in the 1990s: Implications for the Future." Presented at Sugar Conference, Miami, Florida, November 1999.

LMC International. A Survey of Sugar and HFCS Field, Factory and Freight Production Costs: 1997 Report.

Schmitz, Andrew "Sugar: The Free Trade Myth and the Reality of European Subsidies." Gainesville, FL: International Working Paper IW95-6, International Agricultural Trade and Development Center, Food and Resource Economics Department, Institute of Food and Agricultural sciences, University of Florida, 1995.

Schmitz, Andrew and Douglas Christian. "The Economics and Politics of U.S. Sugar Policy." in The Economics and Politics of World Sugar Policies, S. V. Marks and K. E. Maskus, editors. Ann Arbor, MI: University of Michigan Press, 1993. 
Schmitz, Andrew and Leo Polopolous. "Alcohol Fuel Tax Policy: Sugar, Corn and the Environment." in Flexible Incentives for the Adoption of Environment Environmental Technologies in Agriculture, Frank Casey, Andrew Schmitz, Scott Swinton, and David Zilberman, editors. Norwell, MA: Kluwer Academic Publishers, 1999.

FNP (2002) Agrianual 2001 Anuario da Agricultura Brasileira, Sao Paulo.

F.O. Licht's (2002) Second Estimate of World Sugar Production, 2001/02, International Sugar and Sweetener Report, Volume 134, Number 7, Feb. 22, Ratzeburg, Germany.

JOB Economica. Weekly Sugar and Alcohol Report, April 4. Sao Paulo, Brazil, 2002.

LMC International. Sugar Commodity Bulletin, February.Oxford, U.K, 2002.

Nastari, Plinio. "Brazil's Strategy of Globalization, and Its Impact on Sugar." Presented at the $10^{\text {th }}$ International Seminar, International Sugar Organization, London, England, November 27-28, 2001.

Peter Buzzanell \& Associates. "The Brazilian Sugar and Alcohol Industry: 2000 and Beyond.” Reston, VA, June 2000.

United States Department of Agriculture. Brazil Sugar Semi-Annual Report. Sao Paulo, Brazil: U.S. Agricultural Trade Office, October 2001. 